\title{
Quantitative autoradiographic study of FSH binding sites in prepubertal ovaries of three strains of rats
}

\author{
D. Monniaux and M. M. de Reviers \\ I.N.R.A. Station de Physiologie de la Reproduction, Nouzilly, 37380 Monnaie, France
}

\begin{abstract}
Summary. Iodinated FSH was injected to 18- and 36-day-old rats of 3 strains $(03,04$ and 12$)$ with different sensitivity to FSH $(12<03<04)$ and autoradiography was performed on histological sections of the labelled ovaries. Specific labelling was quantified by microphotometry on histological slides, on granulosa cells of individual follicles with different sizes ( $>80 \mu \mathrm{m}$ diameter) and qualities.

In small preantral follicles $(<160 \mu \mathrm{m}$ diameter) the labelling was low and homogeneous within the granulosa; it increased between 18 and 36 days of age in the 3 strains. At 36 days, ovaries were characterized by the presence of large preantral and antral follicles with a higher labelling in the outer layers of granulosa (near the theca), compared to the inner layers. In definitely atretic follicles, a loss of binding sites was detected in the outer layers. In rats of Strains 03 and 04, the number of binding sites for FSH in the outer layers of granulosa of follicles with a diameter of $>160 \mu \mathrm{m}$ increased with follicular size; no change was detected in follicles of Strain 12 rats. The low number of binding sites for FSH and the lack of terminal maturation which characterized the follicles of strain 12 rats can be related to the poor and delayed follicular development, the low sensitivity to exogenous FSH and the low fertility of the animals of this strain.
\end{abstract}

Keywords: FSH binding; granulosa; follicular growth; rat ovary; quantitative autoradiography; strains of rats

\section{Introduction}

The 3 strains of Wistar rats, 03, 04, 12 (I.N.R.A.), have been genetically isolated for their different sensitivity to exogenous FSH in the Steelman-Pohley test $(12<03<04)$ in previous studies (Mauléon \& Rao, 1963; Mauléon \& Pelletier, 1964). In further studies, the 3 strains have been characterized during prepubertal and adult life for their fertility (Mauleon \& Pelletier, 1964), ovulation rate (Land et al., 1974), ovulatory response to PMSG (Mariana, 1974), gonadotrophin concentrations in pituitary and plasma (de Reviers \& Terqui, 1976) and follicular populations (de Reviers \& Terqui, 1976; de Reviers \& Mauléon, 1979). It is well established now that FSH stimulates follicular growth, but in these strains of rats discrepancies were observed between follicular development and plasma FSH values: for example, rats of Strain 12 have a lower sensitivity to FSH, a lower number of follicles and a delay in follicular development between Days 12 and 32 of life, compared to the other strains, although plasma FSH concentrations are higher than those of the other strains (de Reviers \& Mauléon, 1979). In the same way, at Day 20 of life there are twice as many antral follicles in ovaries of Strain 04 rats as in ovaries of Strain 03 rats and no significant differences between plasma FSH values (de Reviers \& Terqui, 1976).

In this study with prepubertal animals we examined whether there were differences in the acquisition of FSH receptors in the 3 strains. Several autoradiographic and biochemical studies have provided evidence for the presence of binding sites for FSH on granulosa cells of different species. However, in rodents, most quantitative results have been obtained by binding studies on 
cell membranes after homogenizing whole ovaries or on granulosa cells released from pools of essentially large preantral and antral follicles; only qualitative results were obtained after autoradiography on histological sections (Midgley, 1973; Zeleznik et al., 1974; Richards et al., 1976; Uilenbroek \& Richards, 1979; Uilenbroek et al., 1980; Uilenbroek \& Van der Linden, 1983; Smith \& Ojeda, 1986; Roy et al., 1987; Sebok et al., 1987). Quantification of autoradiographies by grain counting has been rarely performed and always on a limited number of large follicles (Shaha \& Greenwald, 1982; Balachandran et al., 1983). No extensive quantitative study of changes in FSH binding during follicular growth and atresia has been performed on individual follicles of different sizes, after autoradiography of binding sites.

In this study, FSH binding sites were quantified on individual follicles of different sizes and qualities, after autoradiography, in ovaries of rats of the 3 strains at two times during prepubertal development.

\section{Materials and Methods}

Animals. Animals of the 3 strains of Wistar rats, $03(\mathrm{~N}=10), 04(\mathrm{~N}=5)$ and $12(\mathrm{~N}=7)$, were bred in our laboratory and were maintained under standardized environmental conditions as reported previously (de Reviers \& Mauléon, $1979)$; i.e. constant photoperiod ( $14 \mathrm{~h} \mathrm{light:10} \mathrm{h} \mathrm{dark);} \mathrm{constant} \mathrm{temperature}\left(21^{\circ} \mathrm{C}\right)$; weaned at 23 days of age; and fed the same ration.

Hormone preparation. FSH used for the injections was the rat FSH Sx 2-I ( $\times 33 \cdot 3$ FSH-NIH-S9) labelled with ${ }^{125}$ I using Iodogen (Pierce, Rockford, IL, USA) as the catalyst (Fraker \& Speck, 1978) and diluted in saline $(9 \mathrm{~g} \mathrm{NaCl} / \mathrm{l})$. Specific activity of the labelled FSH was $\sim 70-80 \mu \mathrm{Ci} / \mu \mathrm{g}$.

Experimental design. Females of each strain were injected with labelled $\mathrm{FSH}(0 \cdot 25 \mu \mathrm{Ci} / \mathrm{g})$ at 18 or 36 days of age (vaginal opening around 40 days). For injection, rats were lightly anaesthetized with ether and the hormone preparation injected through the jugular vein. The females were slaughtered $1 \mathrm{~h}$ after injection, the ovaries were dissected out and fixed in Bouin-Hollande solution. Non-specific labelling was assessed by injecting a 500 -fold excess of FSH together with the labelled hormone in 2 animals. After embedding in paraffin wax, 1 ovary per animal was sectioned serially at $5 \mu \mathrm{m}$. Sections were mounted and stained with Feulgen. For autoradiography, slides were dipped in Ilford K5 emulsion diluted $1 / 1(\mathrm{v} / \mathrm{v})$ with distilled water, air dried, exposed for 4 weeks at $4^{\circ} \mathrm{C}$, then developed and fixed by classical procedures.

Microscopic quantitative analysis of autoradiography. Individual follicles $>80 \mu \mathrm{m}$ in diameter (49I and 468 follicles in 18-day-old and 36-day-old rats, respectively) were analysed for size, quality and labelling. The area of each follicle (limited by the basal layer of the granulosa) was measured using a semi-automatic Image Analysis System (A.S.M. Leitz, Wetzlar, West Germany). Follicles were then allocated to 9 size classes according to diameter, with limits in geometric progression (ratio: 1.26; Table 1). Using classic histological criteria, follicles were judged as normal (no pycnosis in granulosa), early atretic (slightly pycnotic granulosa) or definitely atretic (numerous pycnotic bodies in granulosa). Microscopic analysis of autoradiographies was performed on ovaries removed after injection of labelled FSH and on ovaries removed after injection of labelled FSH together with an excess of unlabelled hormone (control animals). This procedure displayed two types of labelling in ovaries: (1) non-specific labelling, mainly related to penetration in vivo of the labelled hormone in the different parts of the ovary; blood vessels and antrum of follicles were especially heavily labelled; and (2) specific labelling, localized on granulosa cells of follicles. In control animals, the labelling of granulosa cells was clearly displaced but it remained high in blood vessels and in antrum (Figs $3 \&$ 4). The quantification of labelling on granulosa cells was performed on the follicles using a microphotometer (M.P.V. Compact, Leitz). This system permitted measurement of the intensity of light reflected on the silver grains distributed in a selected area of the slide; the incident light beam was projected on the slides in a circular field with a diameter adjusted to $20 \mu \mathrm{m}$ by the aperture of diaphragm. We obtained with this system a good linear relationship between the number of silver grains in the field of measurement and the intensity of reflected light expressed in arbitrary units $(r=0.99)$. According to the distribution of silver grains within the granulosa of follicles, 3 types of follicles were defined.

(a) Type 1 with homogeneous labelling on granulosa cells (Fig. 1); labelling was estimated from 5 measurements per follicle, in random fields of the granulosa.

(b) Type 2 with a high labelling in the outer layers of granulosa (basal layers) and a low labelling in the inner layers (near the antrum or the oocyte) (Fig. 2). For each follicle, we estimated the labelling in the outer layers and the labelling in the inner layers from 4 measurements at random in fields of each part.

(c) Type 3 with a gradient of labelling between the outer and the inner layers of granulosa cells (Fig. 3). Using an ocular micrometer with a distance of $35 \mu \mathrm{m}$ between 2 graduations, changes in labelling intensity of granulosa cells between the theca and the antrum were measured ( 5 measurements in the thickness of granulosa). For each follicle, this gradient was estimated from analysis of 3 random places in the granulosa. 

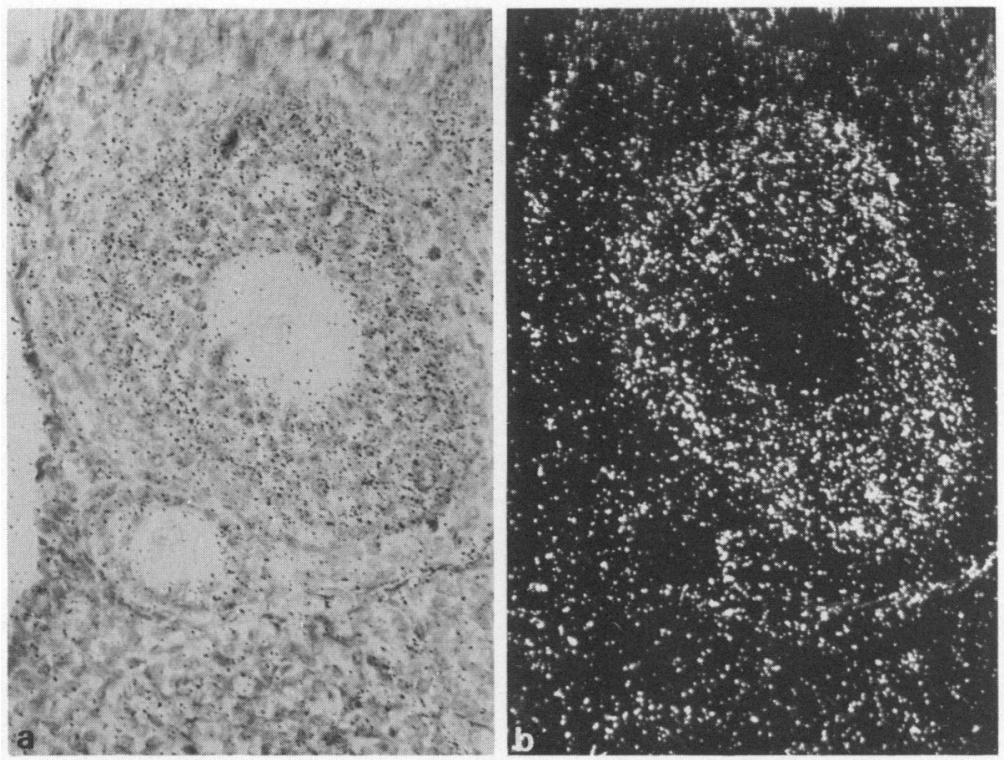

Fig. 1. Follicle of Type 1 with homogeneous labelling within the granulosa. (a) Bright field; (b) dark field. $\times 250$.
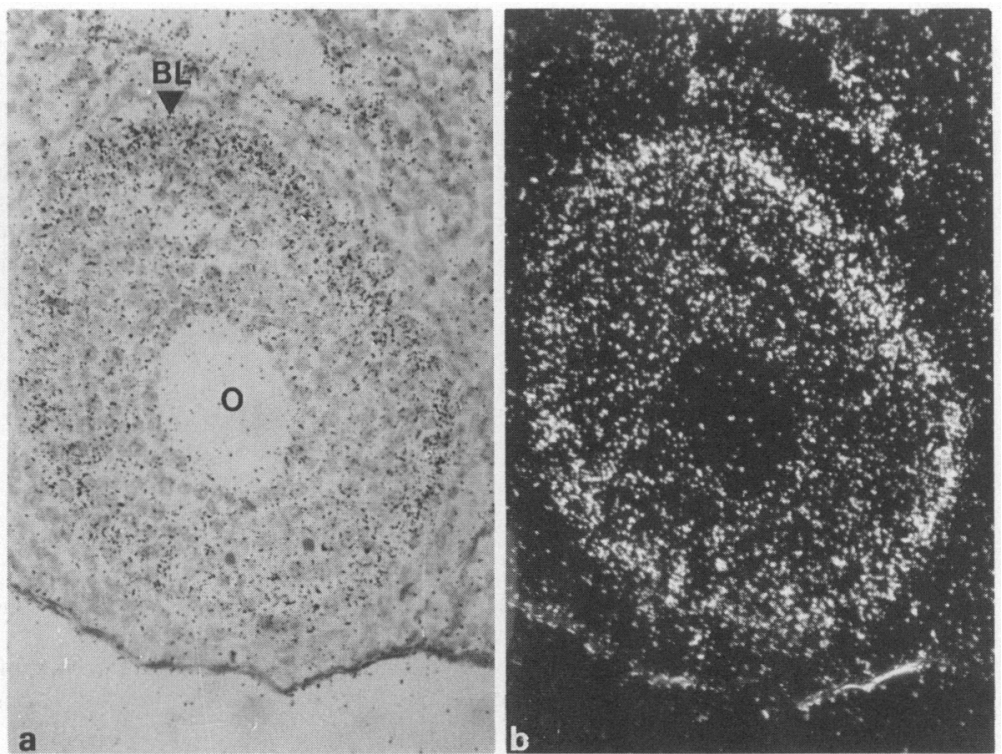

Fig. 2. Follicle of Type 2 with heterogeneous labelling within the granulosa; the labelling of the outer layers (near the basal layer: BL) is higher than the labelling of the inner layers (near the oocyte: $\mathrm{O}$ ). (a) Bright field; (b) dark field. $\times 250$. 

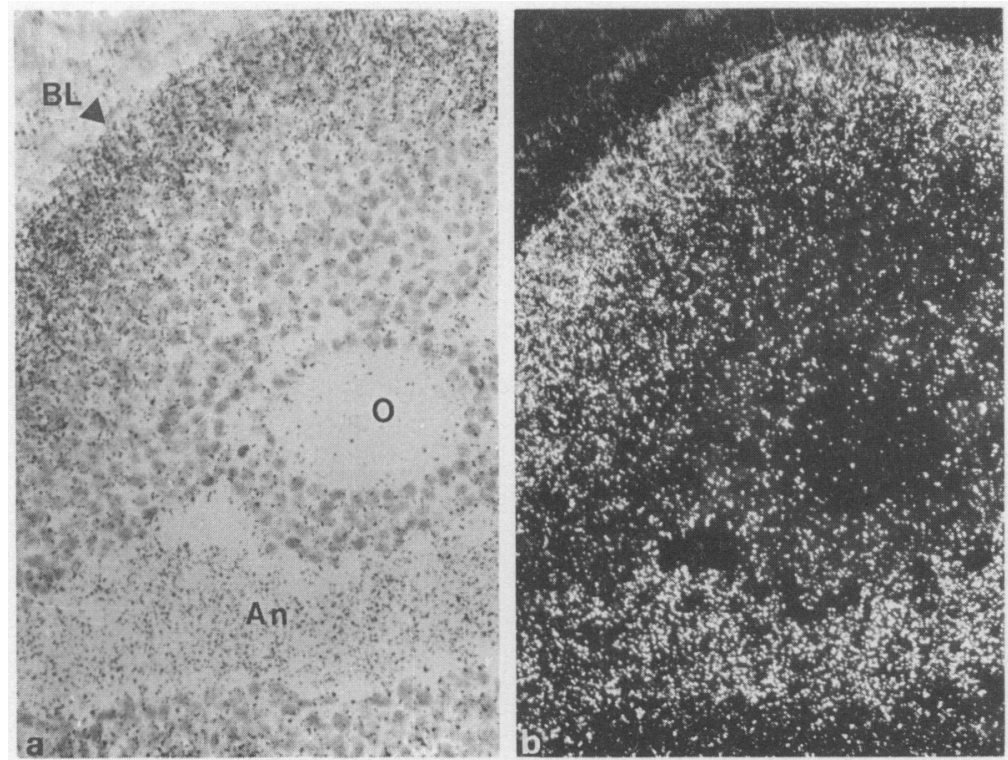

Fig. 3. Labelling of the granulosa in a follicle of Type 3. The labelling is particularly high near the basal layer (BL) and decreases steadily in the inner layers (near the antrum: An). (a) Bright field; (b) dark field. $\times 250$.
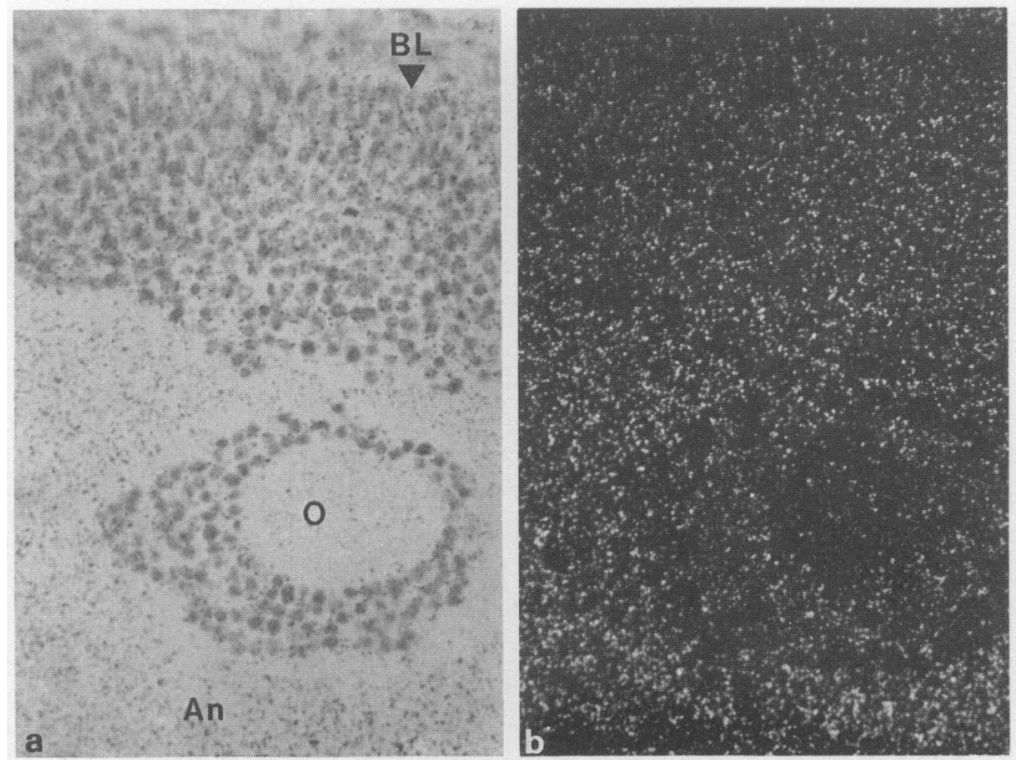

Fig. 4. Labelling of the granulosa in a follicle of Type 3 in a control animal. The binding of labelled FSH on granulosa cells is inhibited by unlabelled FSH, indicating the specificity of the binding sites; the labelling remains high in the antrum (An). (a) Bright field; (b) dark field. $\times 250$. 
The labelling values were in all cases expressed as the intensity of light reflected on silver grains (arbitrary units) per 10 granulosa cells. This required an estimation of the cellular density in granulosa. Using a circular reticle, the estimated cellular density was 16.5 cells $/ 100 \mu \mathrm{m}^{2}$ for large follicles (size classes 5-9) and 18.7 cells $/ 1000 \mu \mathrm{m}^{2}$ for small follicles (size classes 1-4) $(P<0.05)$. The cellular density in the outer layers and in the inner layers of granulosa of large follicles was not significantly different.

Statistical methods. The normality of data was tested using the $\chi^{2}$ test of Pearson. When the data were normally distributed, the effects of the strain, the age of the animals and the size of the follicles on the intensity of labelling were tested using one-way analysis of variance. When the distribution was not normal, the Kruskal-Wallis analysis of variance was used. Tests of associations were made using the correlation coefficient.

\section{Results}

Examination of labelled follicles in the rat ovaries, after injection of ${ }^{125}$ I-labelled FSH to the animals, allowed allocation to 3 types, as described above. Follicles of Type 1, with homogeneous labelling in the granulosa, were essentially small follicles. Follicles of Type 2, with high labelling in the basal layers of granulosa were medium-sized follicles. Follicles of Type 3, with a gradient of labelling, were large follicles. However, in a given size class, follicles of different types could be found (Table 1).

Table 1. Distribution of the different types of labelled follicles in the size classes

\begin{tabular}{lcccc}
\hline \multirow{2}{*}{$\begin{array}{l}\text { Size } \\
\text { class }\end{array}$} & $\begin{array}{c}\text { Diameter } \\
(\mu \mathrm{m})\end{array}$ & \multicolumn{3}{c}{ Follicles } \\
\cline { 3 - 5 } & Type 1 & Type 2 & Type 3 \\
\hline 1 & $80-101$ & + & & \\
2 & $101-127$ & + & & \\
3 & $127-159$ & + & + & \\
4 & $159-201$ & + & + & + \\
5 & $201-253$ & + & + & + \\
6 & $253-319$ & & + & + \\
7 & $319-400$ & & & + \\
8 & $400-504$ & & & + \\
9 & $504-635$ & & & + \\
\hline
\end{tabular}

In the ovaries of the 18-day-old animals, small follicles of Type 1 were found almost exclusively; in the ovaries of the 36-day-old animals, the 3 types of follicles could be analysed.

\section{Labelling of small follicles of Type I in 18-day-old and 36-day-old rats}

The labelling of normal follicles of Type 1 in size classes 1-5 was quantified in the ovaries of animals of the 3 strains.

In 18-day-old rats, 491 follicles were studied. The labelling of granulosa cells did not change between size classes 1 and 4 in follicles of rats of Strains 03 and 04; a slight increase was detected in follicles of Strain 12 rats $(P<0.01)$. The labelling in ovaries of 18 -day-old rats was significantly different between strains $(P<0.001)$; the number of specific binding sites for FSH was particularly high in follicles of Strain 03 rats (Fig. 5a).

In 36-day-old rats, 162 follicles were studied. The increase of the labelling was not significant between size classes 1 and 5 in follicles of rats of Strains 03 and 12; a slight increase was observed in follicles of Strain 04 rats $(P<0.01)$. The labelling of follicles in 36-day-old rats was significantly different between strains $(P<0.001)$; at this age the number of specific binding sites for FSH was particularly low in follicles of Strain 12 rats (Fig. 5b). 
To detect changes in labelling with age, for each strain the labelling of follicles in 18-day-old rats was compared to the labelling in 36-day-old rats in the same size classes of follicles. For each of the 3 strains, the labelling of small follicles increased significantly between 18 and 36 days of age $(P<0.001)$ (Fig. 5a, b). The increase was particularly evident in follicles of rats of Strain 04. Therefore, between 18 and 36 days of age, for each strain, the number of FSH specific receptors per cell had increased in small follicles of Type 1.
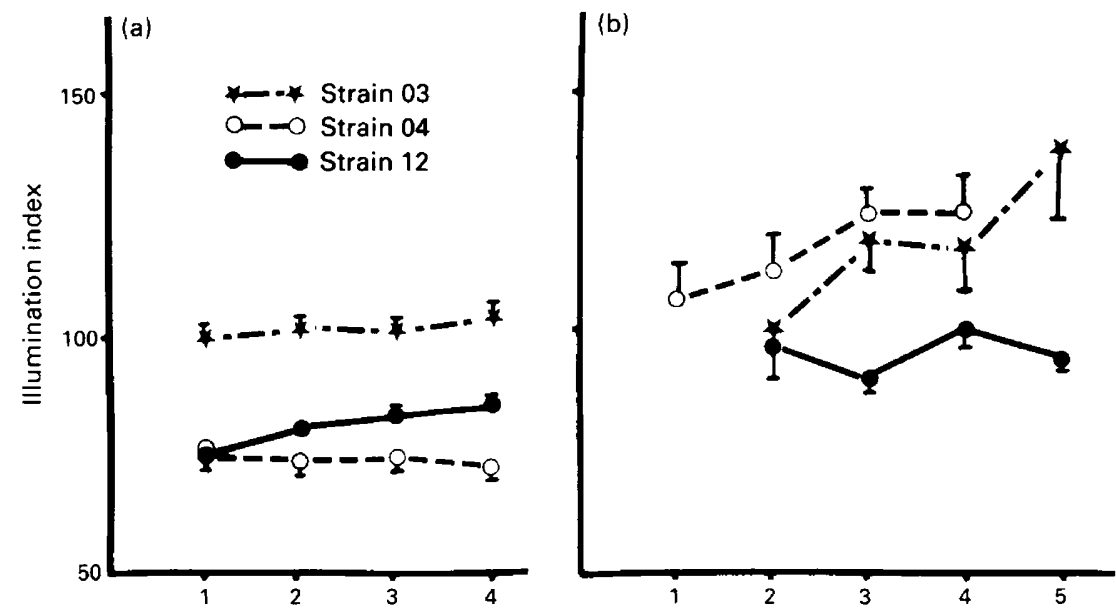

Size class no.

Fig. 5. Changes in labelling of normal small follicles of Type 1 in 18-day-old (a) and 36-day-old (b) rats of the 3 strains with size of follicles. In 18-day-old rats, 244, 48 and 199 follicles in Strains 03, 04 and 12, respectively, were studied. In 36-day-old rats, 54, 65 and 43 follicles in Strains 03,04 and 12, respectively, were studied. Labelling is expressed as the intensity of light reflected on silver grains per 10 granulosa cells (arbitrary units). Values are mean \pm s.e.m. for $0-113$ follicles at each point.

\section{Labelling of follicles of Types 2 and 3 in 36-day-old rats}

Medium-sized and large follicles were characterized by heterogeneous labelling within the granulosa cell layers, with the outer layers more heavily labelled than the inner layers. The percentage of follicles with heterogeneous labelling in granulosa increased between size classes 3 and 5; in ovaries of Strain 04 rats, this type of labelling appeared at a smaller follicular size (Table 2).

Table 2. Percentage of follicles with heterogeneous labelling within the granulosa cell layers in the 3 strains of rats

\begin{tabular}{|c|c|c|c|}
\hline $\begin{array}{l}\text { Size } \\
\text { class }\end{array}$ & Strain 03 & Strain 04 & Strain 12 \\
\hline$<3$ & (7) & $0 \quad(18)$ & (4) \\
\hline 3 & $\begin{array}{ll}0 & \text { (26) }\end{array}$ & $9 \cdot 1$ (33) & $\begin{array}{ll}0 & \text { (23) }\end{array}$ \\
\hline 4 & 41.9 (31) & $46 \cdot 7(30)$ & $36 \cdot 3$ \\
\hline 5 & $90 \cdot 0(30)$ & $100 \cdot 0(22)$ & $80 \cdot 0(10)$ \\
\hline$>5$ & $100 \cdot 0(64)$ & $100 \cdot 0(66)$ & $100.0(23)$ \\
\hline
\end{tabular}

Values in parentheses are the number of follicles studied. 
Type 2 follicles. The labelling of the outer layers of granulosa was highly correlated to the labelling of the inner layers $(r=0.84 ; N=67 ; P<0.001)$. The labelling of the outer layers of granulosa increased slightly between size classes 4 and 6 in follicles of Strains $04(P<0.05)$ and 12 $(P<0.05)$ rats. When rats of the 3 strains were compared, the labelling of the outer layers was significantly different between strains $(P<0.05)$; differences were not significant for the inner layers (Table 3). Thus, in ovaries of 36-day-old rats, the number of specific binding sites for FSH in the outer layers of follicles of Type 2 differed between strains and was particularly low in Strain 12.

Table 3. Mean (s.e.m.) labelling of the outer layers and the inner layers of granulosa in normal follicles of Type 2 (size classes 4-6): labelling is expressed as the intensity of light reflected on silver grains (arbitrary units) per 10 cells

\begin{tabular}{lccc}
\hline Strain & $\begin{array}{c}\text { Outer layers } \\
\text { of granulosa }\end{array}$ & $\begin{array}{c}\text { Inner layers } \\
\text { of granulosa }\end{array}$ & $\begin{array}{c}\text { No. of } \\
\text { follicles }\end{array}$ \\
\hline 03 & $151 \cdot 5(5 \cdot 5)$ & $107.5(3 \cdot 2)$ & 34 \\
04 & $164.6(8 \cdot 5)$ & $119.3(7 \cdot 7)$ & 16 \\
12 & $134 \cdot 6(4 \cdot 4)$ & $104.2(1 \cdot 9)$ & 17 \\
\hline
\end{tabular}

The labelling of follicles of Type 2 was compared to the labelling of follicles of Type 1 (homogeneous labelling) in 36-day-old rats. Comparisons were made in the same size classes of follicles. In each strain, the labelling of the inner layers in follicles of Type 2 was not different from the labelling of follicles of Type 1; however, the labelling of the outer layers in follicles of Type 2 was higher than that of follicles of Type 1 in the 3 strains (Table 4). In size classes $3-5$, follicles in the 3 strains of rats acquire additional specific binding sites for FSH in their outer layers during differentiation.

Table 4. Mean (s.e.m.) labelling of follicles $(n)$ of Types 1 and 2 in the same size classes: labelling is expressed as the intensity of light reflected on silver grains (arbitrary units) per 10 cells

\begin{tabular}{|c|c|c|c|c|}
\hline \multirow[b]{2}{*}{ Strain } & \multirow{2}{*}{$\begin{array}{l}\text { Labelling } \\
\text { of follicles } \\
\text { of Type } 1\end{array}$} & \multicolumn{2}{|c|}{$\begin{array}{c}\text { Labelling of follicles } \\
\text { of Type } 2\end{array}$} & \multirow{2}{*}{$\begin{array}{l}\text { Size } \\
\text { class }\end{array}$} \\
\hline & & Inner layers & Outer layers & \\
\hline 03 & $\begin{array}{c}119 \cdot 8(7 \cdot 1) \\
n=21\end{array}$ & $\begin{array}{c}107.0(3.4) \\
n=31\end{array}$ & $\begin{array}{c}150.4(5.9)^{* *} \\
n=31\end{array}$ & $4-5$ \\
\hline 04 & $\begin{array}{c}125 \cdot 8(4 \cdot 0) \\
n=47\end{array}$ & $\begin{array}{c}111.0(6.6) \\
n=11\end{array}$ & $\begin{array}{c}149 \cdot 2(8 \cdot 9)^{*} \\
n=11\end{array}$ & $3-4$ \\
\hline 12 & $\begin{array}{c}100 \cdot 3(3 \cdot 4) \\
n=16\end{array}$ & $\begin{array}{c}104 \cdot 0(2 \cdot 1) \\
n=15\end{array}$ & $\begin{array}{c}132 \cdot 1(3 \cdot 1)^{* * * *} \\
n=15\end{array}$ & $4-5$ \\
\hline
\end{tabular}

Type 3 follicles. In these follicles a gradient of labelling was estimated, between the basal layer and the antrum, in the granulosa of 178 normal follicles and 39 atretic follicles (size classes 4-9). The labelling of the outer layers of granulosa was highly correlated to the labelling of the inner layers, measured at selected distances from the basal layer (Table 5). In normal follicles of the 3 strains, the number of binding sites for FSH decreased steadily between the basal layer of granulosa 
Table 5. Values of the correlation coefficients between the labelling* of different fields of measurements within granulosa cells of normal follicles of Type 3

\begin{tabular}{lccccc}
\hline $\begin{array}{l}\text { Distance to the } \\
\text { basal layer of } \\
\text { granulosa }(\mu \mathrm{m})\end{array}$ & 17.5 & 35 & 70 & 105 & 140 \\
\hline 17.5 & 1 & 0.89 & 0.73 & 0.59 & 0.48 \\
& & $(178)$ & $(178)$ & $(158)$ & $(82)$ \\
35 & & 1 & 0.84 & 0.70 & 0.62 \\
& & & $(178)$ & $(158)$ & $(82)$ \\
70 & & 1 & 0.88 & 0.77 \\
& & & & $(158)$ & $(82)$ \\
105 & & & 1 & 0.80 \\
& & & & & $(82)$ \\
140 & & & & 1 \\
\hline
\end{tabular}

*For each follicle, the labelling was quantified at selected distances to the basal layer of the follicle, in the thickness of granulosa.

Values in parentheses are the number of follicles studied; this number is lower for measurements at distances $>70 \mu \mathrm{m}$ to the basal layer, owing to the thickness of the granulosa which did not allow 5 measurements in all the follicles.

All the values of correlation coefficients are significant $(P<0 \cdot 001)$.

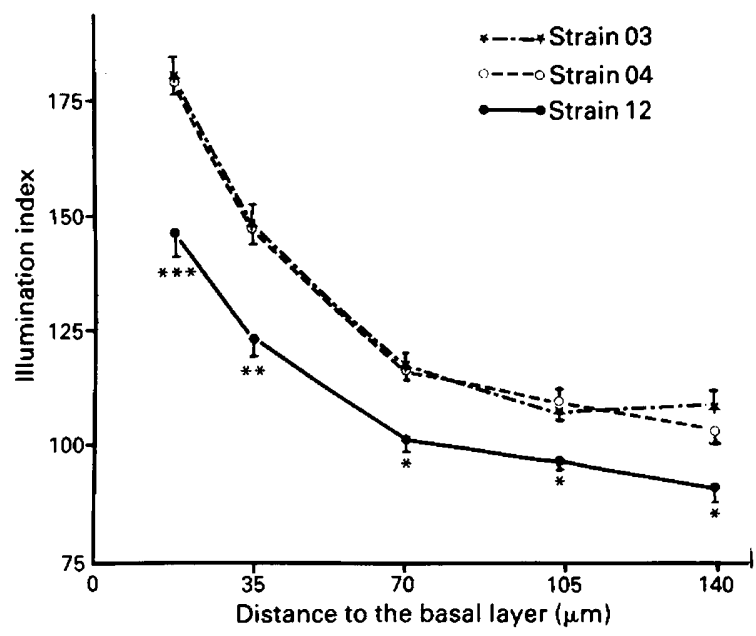

Fig. 6. Changes in labelling of normal large follicles of Type 3 with the distance of the field of measurement to the basal layer of follicles. Follicles of all size classes are pooled in each strain of rats. Labelling is expressed as the intensity of light reflected on silver grains per 10 granulosa cells (arbitrary units). Values are mean \pm s.e.m. ${ }^{*} P<0.05 ;{ }^{* *} P<0.01$; ${ }^{* * *} P<0.001$, compared to the labelling of granulosa at the same distance to the basal layer in rats of Strains 03 and 04 . 
and the antrum; the labelling was significantly lower in follicles of Strain 12 rats, whatever the distance to the basal layer (Fig. 6).

Due to the low number of atretic follicles, the effects of atresia on labelling were studied on a pool of follicles from rats of the 3 strains. No change in labelling was detected in early atretic follicles, compared to normal ones. However, there was a decrease in the labelling of the outer layers of definitely atretic follicles (Fig. 7).

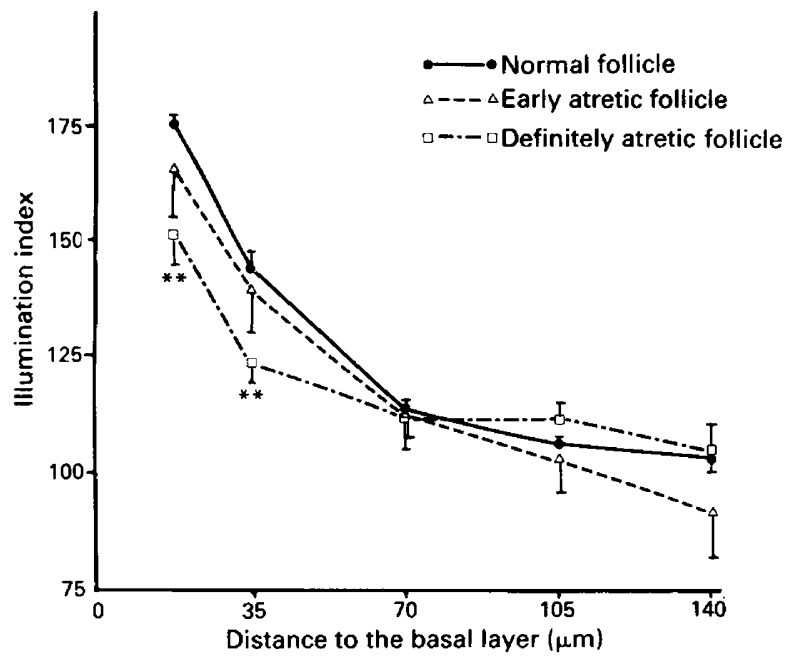

Fig. 7. Effect of atresia on labelling of granulosa in follicles of Type 3. Follicles of all size classes in the 3 strains are pooled: 178 normal follicles (70,86 and 22 follicles in Strains 03, 04 and 12, respectively) and 39 atretic follicles (14,23 and 2 follicles in Strains 03, 04 and 12, respectively) are compared for labelling. Labelling is expressed as the intensity of light reflected on silver grains per 10 granulosa cells (arbitrary units). Values are mean \pm s.e.m. ${ }^{* *} P<0 \cdot 01$, compared to the labelling of granulosa at the same distance to the basal layer, in normal follicles.

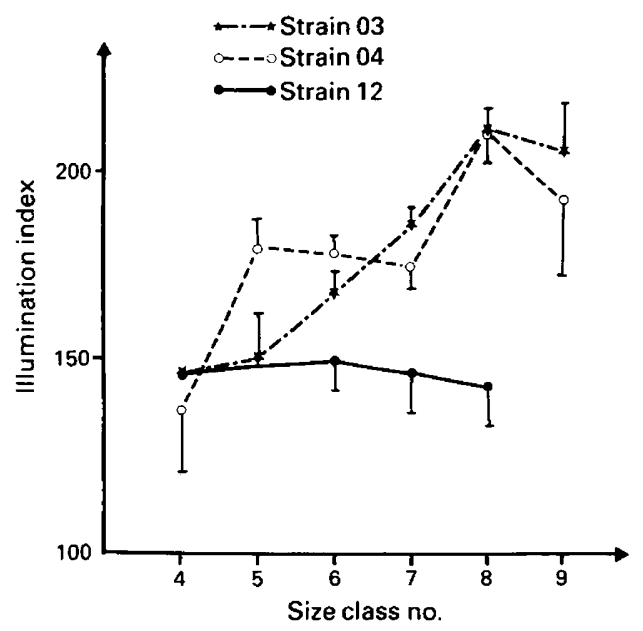

Fig. 8. Changes in labelling of the outer layers of normal follicles of Type 3 in the 3 strains with the size of follicles. The labelling was measured in all the follicles at $17.5 \mu \mathrm{m}$ from the basal layer. Labelling is expressed as the intensity of light reflected on silver grains per 10 granulosa cells (arbitrary units). Values are mean \pm s.e.m. 
In normal follicles, when size classes were considered, the labelling of the outer layers of follicles (distance to the basal layer $<105 \mu \mathrm{m}$ ) increased between size classes 4 and 9 in rats of Strains 03 $(P<0.001)$ and $04(P<0.001)$; no change was detected in follicles of Strain 12 rats. Changes in the labelling of the outer layer, measured at $17.5 \mu \mathrm{m}$ of the basal layer, are depicted for the 3 strains in Fig. 8. With the exception of follicles of Strain 12 rats, therefore, large follicles in the size classes 4-9 acquire additional specific binding sites in the outer layers of the granulosa during terminal differentiation.

\section{Discussion}

In a previous autoradiographic study of the rat ovary, Presl et al. (1974) found FSH receptors on follicles with 2 or more layers of granulosa cells. Further studies indicated the presence of a higher labelling for FSH in the outer layers of granulosa of large antral follicles but no quantification was made (Uilenbroek \& Richards, 1979; Sebok et al., 1987). In the hamster, a quantification of FSH binding sites during follicular growth was performed by biochemical procedures on pools of follicles (Roy et al., 1987); however, for preantral follicles, values were very low and frequently undetectable. The present study is the first extensive work of quantification of changes in FSH binding sites during follicular growth in follicles larger than $80 \mu \mathrm{m}$ diameter in the rat.

In preantral follicles (size classes 1-4), the number of FSH binding sites does not change with follicular size and the labelling is homogeneous within the granulosa. In size classes 46 the follicles mature and acquire additional binding sites in the outer layers of granulosa. Then, during terminal follicular growth, the number of binding sites per cell increases in the outer layers of antral follicles (with the exception of follicles in Strain 12 rats). These results are in general agreement with the existence of heterogeneity in granulosa cells of large antral follicles in rats: the outer layers of follicles have a maximal density of LH receptors (Amsterdam et al., 1975; Bortolussi et al., 1977), are more active in steroid production (Zoller \& Weisz, 1978, 1979), and have fewer prolactin receptors (Dunaif et al., 1982). In immature hypophysectomized rats treated with diethylstilboestrol, the existence of subpopulations of granulosa cells with different sedimentation properties and responsiveness to FSH has been reported (Kasson et al., 1985); our results confirm this heterogeneity and specify its distribution in ovaries of immature normal rats. During follicular maturation, the acquisition of additional binding sites for FSH is determined by the place of the cells within the follicle. The outer layers of granulosa cells in antral follicles have a maximal density of FSH receptors per cell and they first loose binding sites during atresia. The loss of binding sites for FSH is significant only in advanced atresia and would be a consequence rather than a cause of the atretic process.

During the prepubertal life of the female rat, plasma FSH concentrations are high around 15 days of age, decline at Day 20 and remain low until the afternoon of the first day of pro-oestrus. The high levels of FSH are probably responsible for the stimulation of follicular growth between 8 and 20 days of age and the appearance of antral follicles in ovaries between 16 and 20 days of age; after 20 days of age, when FSH concentrations are low, the rate of initiation of follicular growth decreases and the rate of atresia increases (Hage et al., 1978; de Reviers \& Mauléon, 1979). Changes in FSH receptor content in the immature ovary have been described with conflicting results (Peluso et al., 1976; Smith White \& Ojeda, 1981; Uilenbroek \& Van der Linden, 1983). These studies were all performed with pools of granulosa cells or on ovarian homogenates and the reasons for discrepancies are probably related to differences of sensitivity in the methods of measurement of the binding sites. In the present study, the number of binding sites for FSH increases in granulosa cells of preantral follicles between 18 and 36 days of age; moreover, the ovaries of 36-day-old rats contain large antral follicles with high labelling of granulosa cells, particularly in the outer layers. The increase in FSH binding observed between 18 and 36 days of age in preantral follicles may be the consequence of a decrease of the number of receptors occupied by endogenous FSH or/and 
of the induction of new binding sites on granulosa cells. We cannot choose between these two possibilities because the experimental design allowed measurement of only the unoccupied sites. However, Smith White \& Ojeda (1981) found that the most rapid increase in FSH receptor content occurred at the time when the serum FSH concentrations were maximal, suggesting that FSH upregulates its own receptors (Richards et al., 1976).

In rats of Strains 03 and 04 , similar changes of $\mathrm{FSH}$ binding during follicular growth were observed. However, in preantral follicles with homogeneous labelling, the number of binding sites for FSH was slightly higher at 36 days of age in ovaries of Strain 04 rats. Follicular maturation was more precocious in rats of Strain 04: the heterogeneous labelling characteristic of large mature follicles appeared at a smaller follicular size, clearly before antrum formation; in the same way, small antral follicles (diameter 200-320 $\mu \mathrm{m}$ ) were more heavily labelled, compared to follicles of the same size in rats of Strain 03. These differences in binding sites for FSH in Strains 03 and 04 can be related to the precocity of follicular development observed during prepubertal life in ovaries of Strain 04 rats (de Reviers \& Terqui, 1976). They can also partly explain the higher sensitivity of this rat strain to FSH in the Steelman-Pohley test.

Follicular maturation in ovaries of rats of Strain 12 is clearly different from the maturation observed in the two other strains: at 36 days of age, follicles of all size classes have fewer binding sites per cell and the number of binding sites in the outer layers of antral follicles does not increase with follicular size during terminal follicular maturation. The weak receptivity to FSH of follicles of all sizes and the lack of terminal maturation of follicles can be related to the low sensitivity to exogenous FSH of Strain 12 rats in the Steelman-Pohley test. Moreover, it can explain the poor and delayed follicular development observed in immature ovaries of these rats (de Reviers \& Terqui, 1976; de Reviers \& Mauléon, 1979), and it could be related to the high rate of sterile adult females in this strain (10.7\% vs 6.0 and $4.9 \%$ in Strains 03 and 04 , respectively). However, surprisingly, animals of Strain 12 have the highest plasma concentrations of FSH during prepubertal life. According to Smith \& Ojeda (1986), the elevated values of FSH during neonatal life are essential for the subsequent appearance of FSH receptors. We propose that the circulating form of FSH in Strain 12 rats would have a low biological activity and would be unable to upregulate its own receptors. Another possibility is the lack of a factor able to enhance the stimulatory action of FSH. Rats of Strain 12 are characterized by a low body weight: for example, at weaning age (23 days of life), the mean ( \pm s.d.) body weights are $50.1 \pm 0.5 \mathrm{~g}(\mathrm{~N}=117), 46.6 \pm 0.5 \mathrm{~g}(\mathrm{~N}=149)$ and $38.6 \pm 0.4 \mathrm{~g}(\mathrm{~N}=133)$, for Strains 03,04 and 12 , respectively. In recent studies, $\mathrm{GH}$ (Hutchinson et al., 1988) and the growth factor IGF-1 (Adashi et al., 1985) were found to enhance the action of FSH in vitro on rat granulosa cells. Low circulating levels of one of these factors could impair both body growth and FSH action on its receptors.

\section{References}

Adashi, E.Y., Resnick, C.E., D'Ercole, A.J., Svoboda, M.E. \& Van Wyk, J.J. (1985) Insulin-like growth factors as intra-ovarian regulators of granulosa cell growth and function. Endocr. Rev. 6, 400-420.

Amsterdam, A., Koch, Y., Lieberman, M.E. \& Lindner, H.R. (1975) Distribution of binding sites for human chorionic gonadotropin in the preovulatory follicle of the rat. J. Cell Biol. 67, 894-900.

Balachandran, P.K., Moodbidri, S.B. \& Nandedkar, T.D. (1983) Autoradiographic analysis of FSH binding during follicular atresia. Experientia 39, 792-793.

Bortolussi, M., Marini, G. \& Dal Lago, A. (1977) Autoradiographic study of the distribution of LH (hCG) receptors in the ovary of untreated and gonadotrophin-primed immature rats. Cell Tiss. Res. 183, 329-342. de Reviers, M.M. \& Mauléon, P. (1979) Evolution of ovarian follicular population and serum gonadotrophins in the prepubertal period of two strains of rats. Annls Biol. anim. Biochim. Biophys. 19, 1745-1756.

de Reviers, M.M. \& Terqui, M. (1976) Ovarian follicular development and gonadotrophin levels during prepubertal life in three strains of rats with different sensitivity to FSH. Annls Biol. anim. Biochim. Biophys. 16, 307-311.

Dunaif, A.W., Zimmerman, E.A., Friesen, H.G. \& Frantz, A.G. (1982) Intracellular localization of prolactin receptor and prolactin in the rat ovary by immunocytochemistry. Endocrinology 110, 1465-1471.

Fraker, P.J. \& Speck, J.C. (1978) Protein and cell membrane iodinations with a sparingly soluble 
chloramide, 1,3,4,6-tetrachloro-3a,6a-diphenylglycoluril. Biochem. Biophys. Res. Commun. 80, 849-857.

Hage, A.J., Groen-Klevant, A.C. \& Welschen, R. (1978) Follicle growth in the immature rat ovary. Acta endocr., Copenh. 88, 375-382.

Hutchinson, L.A., Findlay, J.K. \& Herington, A.C. (1988) Growth hormone and insulin-like growth factor-I accelerate PMSG-induced differentiation of granulosa cells. Molec. cell. Endocr. 55, 61-69.

Kasson, B.G., Meidan, R., Davoren, J.B. \& Hsueh, A.J.W. (1985) Identification of subpopulations of rat granulosa cells: sedimentation properties and hormonal responsiveness. Endocrinology 117, 1027-1034.

Land, R.B., de Reviers, M.M., Thompson, R. \& Mauléon, P. (1974) Quantitative physiological studies of genetic variation in the ovarian activity of the rat. J. Reprod. Fert. 38, 29-39.

Mariana, J.C. (1974) Etude du nombre d'ovulations après superovulation induite par PMSG chez trois souches de rattes adultes. Annls Biol. anim. Biochim. Biophys. 14, 623-632.

Mauléon, P. \& Pelletier, J. (1964) Variations génétiques du fonctionnement hypophysaire de trois souches de rattes immatures. Relations avec la fertilité. Annls Biol. anim. Biochim. Biophys. 4, 105-112.

Mauléon, P. \& Rao, K.H. (1963) Variations génétiques des populations folliculaires dans les ovaires de rattes impubères. Annls Biol. anim. Biochim. Biophys. 3, 21-31.

Midgley, A.R. (1973) Autoradiographic analysis of gonadotropin binding to rat ovarian tissue sections. Adv. exp. Med. Biol. 36, 365-378.

Peluso, J.J., Steger, R.W. \& Hafez, E.S.E. (1976) Development of gonadotrophin-binding sites in the immature rat ovary. J. Reprod. Fert. 47, 55-58.

Presl, J., Pospisil, J., Figarova, V. \& Krabec Z. (1974) Stage-dependent changes in binding of iodinated FSH during ovarian follicle maturation in rats. Endocr. exp. 8, 291-297.

Richards, J.S., Ireland, J.J., Rao, M.C., Bernath, G.A., Midgley, A.R. \& Reichert, L.E. (1976) Ovarian follicular development in the rat: hormone receptor regulation by estradiol, follicle stimulating hormone and luteinizing hormone. Endocrinology 99, 15621570.

Roy, S.K., Wang, S.C. \& Greenwald, G.S. (1987) Radioreceptor and autoradiographic analysis of $\mathrm{FSH}, \mathrm{hCG}$ and prolactin binding sites in primary to antral hamster follicles during the periovulatory period. $J$. Reprod. Fert. 79, 307-313.

Sebok, K., Sairam, M.R., Cantin, M. \& Mohapatra, S.K. (1987) Distribution of follitropin and deglycosylated follitropin in the rat: a quantitative and radioautographic study. Molec. cell. Endocr. 52, 185-197.

Shaha, C. \& Greenwald, G.S. (1982) Autoradiographic analysis of changes in ovarian binding of FSH and hCG during induced follicular atresia in the hamster. J. Reprod. Fert. 66, 197-201.

Smith, S.S. \& Ojeda, S.R. (1986) Neonatal release of gonadotropins is essential for development of ovarian follicle-stimulating hormone receptors. Biol. Reprod. 34, 219-227.

Smith White, S. \& Ojeda, S.R. (1981) Changes in ovarian luteinizing hormone and follicle-stimulating hormone receptor content and in gonadotropin-induced ornithine decarboxylase activity during prepubertal and pubertal development of the female rat. Endocrinology 109, 152-161.

Uilenbroek, J.Th.J. \& Richards, J.S. (1979) Ovarian follicular development during the rat estrous cycle: gonadotropin receptors and follicular responsiveness. Biol. Reprod. 20, 1159-1165.

Uilenbroek, J.Th.J. \& Van der Linden, R. (1983) Changes in gonadotrophin binding to rat ovaries during sexual maturation. Acta endocr., Copenh. 103, 413-419.

Uilenbroek, J.Th.J., Woutersen, P.J.A. \& Van der Shoot, P. (1980) Atresia of preovulatory follicles: gonadotropin binding and steroidogenic activity. Biol. Reprod. 23, 219-229.

Zeleznik, A.J., Midgley, A.R. \& Reichert, L.E. (1974) Granulosa cell maturation in the rat: increased binding of human chorionic gonadotropin following treatment with follicle-stimulating hormone in vivo. Endocrinology 95, 818-825.

Zoller, L.C. \& Weisz, J. (1978) Identification of cytochrome P.450 and its distribution in the membrana granulosa of the preovulatory follicle, using quantitative cytochemistry. Endocrinology 103, 310-313.

Zoller, L.C. \& Weisz, J. (1979) A quantitative cytochemical study of glucose-6-phosphate dehydrogenase and $\Delta^{5}-3 \beta$-hydroxysteroid dehydrogenase activity in the membrana granulosa of the ovulable type of follicle of the rat. Histochemistry 62, 125-135.

Received 3 May 1988 